\title{
Hydrocephalus in Sudan; Types, Management and Outcome
}

\author{
Mohammed Awad Elzain* and Abubakr Darrag Salim \\ National Center for Neurological Sciences, Khartoum, Sudan
}

Submission: November 25, 2016; Published: January 05, 2017

*Corresponding author: Mohammed Awad Elzain, National Center for Neurological Sciences, Khartoum, Sudan, Tel: +249912808126; Email:alkarsani@yahoo.com

\begin{abstract}
The incidence of congenital hydrocephalus is still very high in Sudan. Most of the patients present late with large head and malnutrition, which make the management very difficult. Materials and method: This study is a retrospective review joining all children younger than 15 years of age who have been operated at the National Center for Neurological Sciences during the period from Aug 2011 to December 2013. The data obtained from a computerized data record system in the center and the patients were clinically assessed by the author when during follow up in the refer clinic. Results: Most patients lie in the age group (birth â€" 3 months) $40.5 \%$. The majority of the cases presented with large head $71.8 \%$. Hydrocephalus secondary to Chiari II malformation represented the commonest etiology of congenital hydrocephalus $(42.7 \%)$ while postmeningitic hydrocephalus was the commonest etiology of secondary hydrocephalus (82.1\%). Fortunately $10.7 \%$ had shunt complications, but only $6 \%$ had early postoperative shunt infection. The commonly found associated congenital CNS anomaly was myelomeningocele $(35.1 \%)$.

Folic acid and supplements were defective in $72.5 \%$ of the pregnant ladies who started to take the folic acid after the end of the first trimester. Four patients found to have problems during pregnancy, 2 of them had malaria, one PIH and one recurrent UTI, however none of the patient had FH of similar condition. Discussion: Most of the patients were from Khartoum and the central area (68.7\%). This is followed by those from the Western part of Sudan (Darfur and Kordofan), as there is a lot of wars and refugees which has created nutritional impact on the ladies in the childbearing age As a result of the poor antenatal follow up and the illiteracy of most of the parents, most of the diagnoses were made late when they notice their baby's head increasing. The presence of associated congenital anomalies makes the management much more difficult. Conclusion: Early detection and management of hydrocephalus should be considered by increasing the awareness of the medical professionals and the general populations. The use of strict meticulous aseptic technique during the operative procedure is crucial in preventing shunt infection and most other serious complications. The ventriculoperitoneal shunt procedure is not an easy one and should be performed by the most experienced neurosurgeon under the most optimum condition.
\end{abstract}

Keywords: Congenital hydrocephalus; Large head; Folic acid deficiency

\section{Introduction}

Hydrocephalus is a common health problem that is associated with aggressive morbidity and mortality [1]. Different types of hydrocephalus may be managed with the placement of the ventriculoperotineal shunt, but the complications related to shunt placement should be identified and managed properly particularly in the first 5 years following shunt placement. A survey done by Albright A.L. in 2010 recruiting seven pediatric neurosurgeons proved that there is no standardized technique or shunt type to prevent shunt complications and the most important issue after shunt implantation is the patient follow up. It was also noticed that, none of the pediatric neurosurgeons operate on asymptomatic patient or do annual follow up images for shunted patients with hydrocephalus beyond 5 years [2].

The most annoying shunt complication is shunt infection which requires urgent shunt removal as the bacterial growth affects the shunt hardware [3]. However when the shunted patients develop meningitis, they should be managed the same as those who have meningitis without shunts and shunt removal here is controversial [3]. Shunt infection caused by coryenebacterium species represents a special challenge as it was found to be resistant to most antibiotics and requires shunt removal [4]. In cases of delayed shunt infections, 
Propionibacterium acnes is believed to be the causative agent and was also found to be very difficult to eradicate even with prolonged antibiotics therapy and also requires shunt removal [5]. Bayston R. suggested that the antibiotic impregnated shunts use may prevent this later type of shunt infections [6].

Brydon H.L. in his study emphasizes the fact that the high CSF protein content does not increase the risk for shunt infection [7]. However these findings are still theoretical and more studies are needed to confirm this. Furthermore, Brydon also published another study 2 years later stating that protein deposition in shunted patients is not the main cause for shunt obstruction [8].

Numerous advances were done to improve the shunt valve manufacturing starting from fixed pressure valves to programmable valves. However, the later have the problem that the valve pressure may be accidently changed upon exposure to a high magnetic power [9]. This problem has been solved with the provision of the ProGAV valve system and its efficiency was proved in the study done by Allin, D.M. in 2006 [9]. Two years later Allin D.M. discovered that Polaris valve may also overcome the problem of accidental re-adjustment and this has been evaluated at UK Shunt Evaluation Laboratory in Cambridge [10].

Shunt nephritis is another rare form of shunt complications and up to the year 1996 only 115 patients were reported in the literature11. This is a reversible form of renal disease caused by shunt infection and can be managed by either prescribing antibiotics only or by both shunt replacement and antibiotic treatment11. The CSF over-drainage upon changing from horizontal to vertical position ( Siphoning effect ) has been known as one of the shunt complication that necessitated the evolution of new shunt devices with anti-siphoning effect like $\mathrm{Z}$ flow hydrocephalus system and Diamond valve $[12,13]$.

Silicon hypersensitivity, an immune response mediated towards the implanted silicone catheters has been also believed to increase the risk for shunt failure. Eymann has suggested the use of animal models to study that immune response in order to understand this phenomenon and to help in improving shunt system manufacturing $[14,15]$. Shunt obstruction is a common complication of shunt implantation that may be diagnosed clinically and confirmed by different imaging techniques. Due to the high dose of radiations associated with repeated CT brains, Goetz suggested the use of infrared-thermography a noninvasive tool to verify shunt patency and this was found to be sensitive in more than $85 \%$ of patients [16].

The nutritional status of the patients with hydrocephalus is an important overlooked factor that may have negative influence on shunt surgery. In India Jain G. found that the post-operative shunt complication rates were significantly higher in the poorly nourished children [17].

Most of the Sudanese children with hydrocephalus were malnourished this is due to fact that the incidence of congenital hydrocephalus together with post meningitic type is still very high in Sudan. Beside that most of the patients present late with large heads this also lead to increase incidence of the complications associated with shunt placement which make the management much more difficult. Therefore we conducted this study to reflect and publish our experience in diagnosing and managing hydrocephalus in Sudan and to show the magnitude of the problem, there are no previous published studies discussing the problems of patients with hydrocephalus in Sudan.

This study is a retrospective review joining all children younger than 15 years of age who have been operated at the National Center for Neurological Sciences during the period from Aug 2011 to December 2013. The data obtained from a computerized data record system entered by the neurosurgical residents and a trained information technology person in the center. Data entered include that obtained from the file, while operative and postoperative data was obtained from the authors and the operating neurosurgeons and entered in the system immediately after surgery and during follow up in the referred clinics. The patients were regularly clinically and radiologically assessed by the authors over 3 years follow up period.

\section{Results}

\section{Sex distribution}

The total number of the patients studied was 131 patients 81 of them were males (61.8\%), and 50 patients (38.2\%) were females (Table 1) (Figure 1).

Table 1: Sex distribution of the patients in the series.I

\begin{tabular}{|c|c|c|}
\hline Gender & Frequency & Percent \\
\hline male & 81 & $61.8 \%$ \\
\hline female & 50 & $38.2 \%$ \\
\hline Total & 131 & $100 \%$ \\
\hline
\end{tabular}

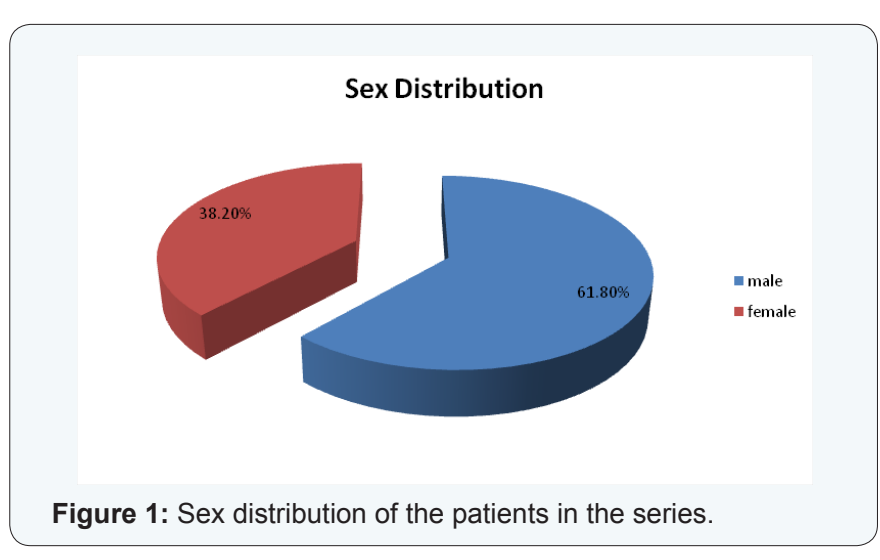

\section{Age distribution}

The youngest patient operated was 15 days old and the oldest was 12 years old with average presentation at 1 year of age (Table 2.1). 
Table 2.1: The statistics of ages for all patients in this series.

\begin{tabular}{|c|c|}
\hline Mean & 11.04 months \\
\hline Median & 5 months \\
\hline Mode & 2 months \\
\hline Minimum & 15 days \\
\hline Maximum & 144 months (12 years) \\
\hline
\end{tabular}

When patients were ranked in groups, it was found that most of them were in the age groups from birth to 6 months $(n=89 / 131,68 \%)$ (Table 2.2) (Figure 2).

Table 2.2: The distribution of patients among the different age groups.

\begin{tabular}{|c|c|c|}
\hline Age in groups & Frequency & Percent \\
\hline Birth - 3 months & 53 & $40.5 \%$ \\
\hline 4 - 6 months & 36 & $27.5 \%$ \\
\hline 7 - 12 months & 25 & $19.1 \%$ \\
\hline 13 months - 3 years & 12 & $9.2 \%$ \\
\hline More than 5 years & 5 & $3.8 \%$ \\
\hline Total & 131 & $100 \%$ \\
\hline
\end{tabular}

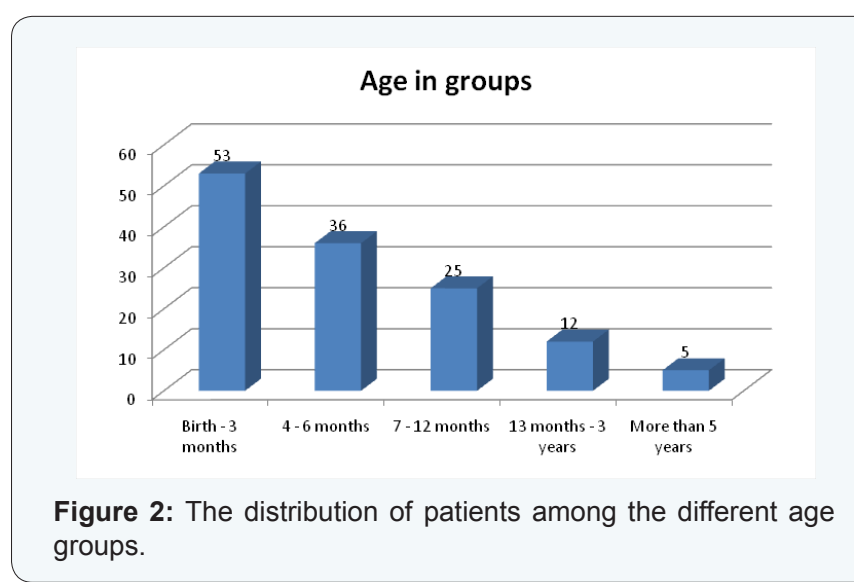

\section{Residence}

Most of the patients in the series were from Khartoum and central areas around Khartoum (the capital of North Sudan) (n=90/131, 68.7\%) (Table 3) (Figure 3).

Table 3: The geographical distribution of the patients among different parts of Sudan.

\begin{tabular}{|c|c|c|}
\hline Residency of origin & Frequency & Percent \\
\hline Khartoum & 46 & $35.1 \%$ \\
\hline central area & 44 & $33.6 \%$ \\
\hline eastern area & 5 & $3.8 \%$ \\
\hline Darfur & 12 & $9.2 \%$ \\
\hline Northern area & 5 & $3.8 \%$ \\
\hline Kordofan & 18 & $13.7 \%$ \\
\hline Southern area & 1 & $0.8 \%$ \\
\hline Total & 131 & $100 \%$ \\
\hline
\end{tabular}

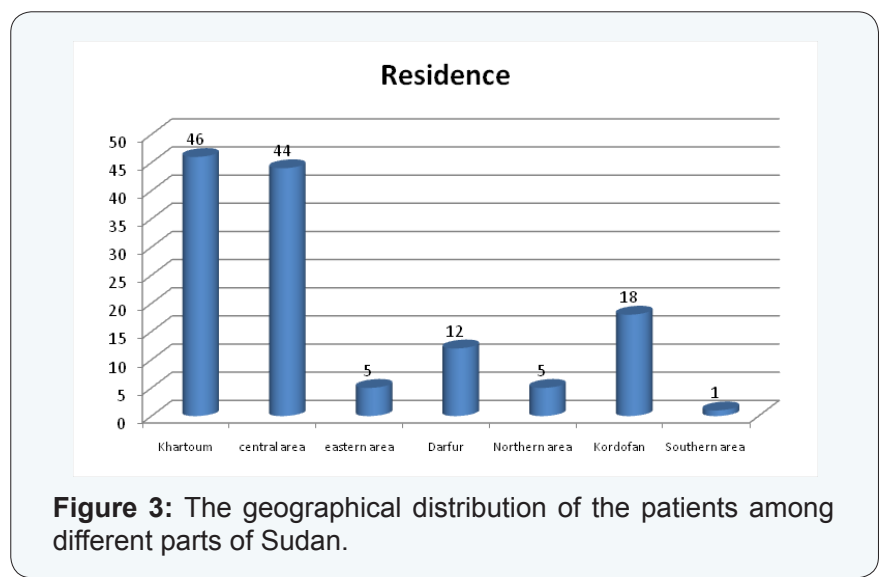

\section{Presentation with large head}

Almost three quarters of patients (n=94/131, 71.8\%) presented with larger head (more than 2 SD "98\%" Head Circumference for age, one percentile for boys and one for girls) as their first presentation and as the first abnormality noticed with their parents (Table 4) (Figure 4).

Table 4: The presentation with large head

\begin{tabular}{|c|c|c|}
\hline $\begin{array}{c}\text { Large head at } \\
\text { presentation }\end{array}$ & Frequency & Percent \\
\hline present & 94 & $71.8 \%$ \\
\hline absent & 37 & $28.2 \%$ \\
\hline Total & 131 & $100 \%$ \\
\hline
\end{tabular}

Large head

Figure 4: The presentation with large head.

\section{Causes and types of hydrocephalus}

Most of the children in this study were having hydrocephalus secondary to Chiari Type II malformation caused by their associated myelomeningocele $(n=44,33.6 \%)$ followed by those with congenital acquiductal stenosis ( $n=40 / 131,30.5 \%)$. Secondary (acquired) hydrocephalus was mainly in a form of postmeningitic hydrocephalus, the diagnosis was made utilizing both clinical and radiological data using CT and MRI scans $(n=20 / 131,15.3 \%)$ (Table $5.1 \& 5.2)$ (Figure $5.1 \& 5.2)$. 
Table 5.1: The distribution of patients with congenital hydrocephalus.

\begin{tabular}{|c|c|c|}
\hline $\begin{array}{c}\text { Type of congenital } \\
\text { hydrocephalus }\end{array}$ & Frequency & Percent \\
\hline $\begin{array}{c}\text { Chiari II } \\
\text { Malformation }\end{array}$ & 44 & $42.7 \%$ \\
\hline Acquiductal stenosis & 40 & $38.8 \%$ \\
\hline Dandy walker & 8 & $7.8 \%$ \\
\hline Hydrancephaly & 3 & $2.9 \%$ \\
\hline porencephalic cyst & 3 & $2.9 \%$ \\
\hline Dandy variant & 3 & $2.9 \%$ \\
\hline $\begin{array}{c}\text { Holoprosencephaly } \\
\text { semilobar type }\end{array}$ & 2 & $1.9 \%$ \\
\hline Total & 103 & $100 \%$ \\
\hline
\end{tabular}

Table 5.2: The distribution of patients with acquired hydrocephalus.

\begin{tabular}{|c|c|c|}
\hline $\begin{array}{c}\text { Type of Acquired } \\
\text { Hydrocephalus }\end{array}$ & Frequency & Percent \\
\hline Postmeningitic & 23 & $82.1 \%$ \\
\hline $\begin{array}{c}\text { Obstructive } \\
\text { (Tumoral) }\end{array}$ & 5 & $17.9 \%$ \\
\hline Total & 28 & $100 \%$ \\
\hline
\end{tabular}

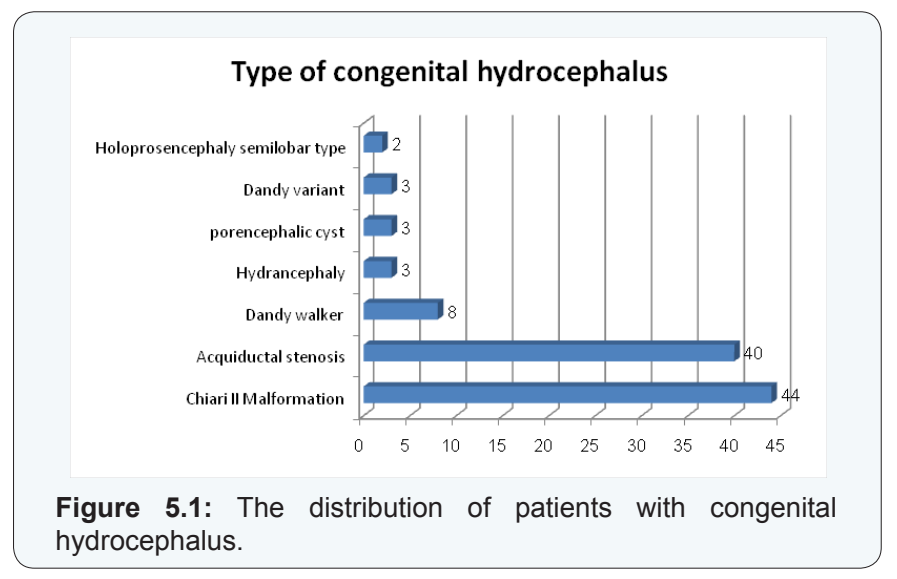

Figure 5.1:
hydrocephalus

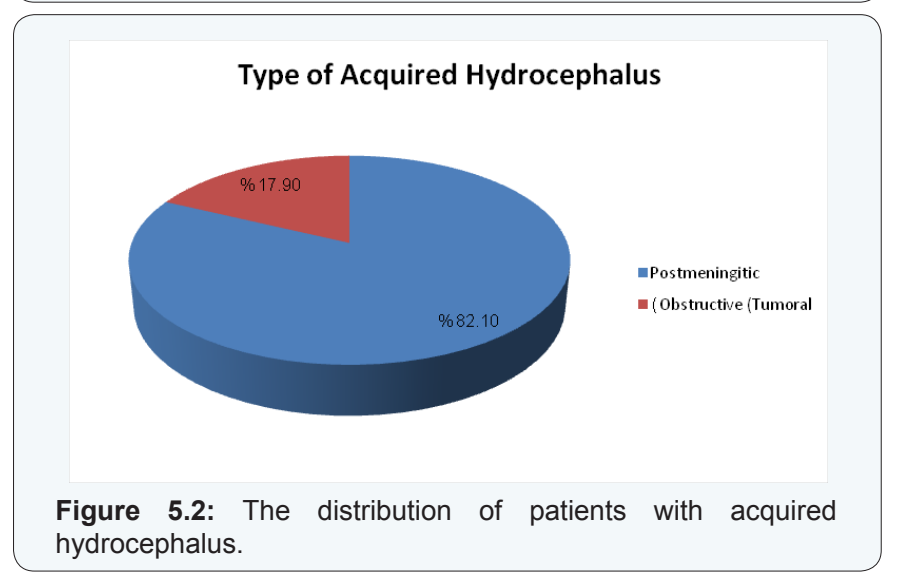

\section{Associated CNS congenital anomalies}

We only mentioned here in this study the congenital CNS anomalies while the other non related congenital anomalies were not mentioned (Table 6).
Table 6: The CNS congenital anomalies associated with hydrocephalus.

\begin{tabular}{|c|c|c|}
\hline $\begin{array}{c}\text { Associated CNS } \\
\text { anomalies }\end{array}$ & Frequency & Percent \\
\hline myelomeningiocele & 46 & $35.1 \%$ \\
\hline encephalocele & 2 & $1.5 \%$ \\
\hline arachnoid cyst & 1 & $0.8 \%$ \\
\hline encephalomalacia & 2 & $1.5 \%$ \\
\hline no & 80 & $61.1 \%$ \\
\hline Total & 131 & $100 \%$ \\
\hline
\end{tabular}

\section{Type of surgery done}

Most of the patients were operated through posterior approach through Keen's point using medium pressure (MP) valves and the ventricular catheters were placed at the occipital horn of the lateral ventricle. In some few cases like those with posterior fossa tumors the ventricular catheter was placed at the frontal horn of the lateral ventricle through Kocher's point. The Y connecter in this study was used mainly for those with Dandy Walker variant in which the posterior fossa cyst was not communicating with the IV ventricle, the EVD was resorted to in patients where frank features of infection like pus or turbid CSF or hemorrhage were encountered during surgery in the stage of ventricular tapping .also cystoperitoneal shunt is patients with localized hydrocephalus. Dandy walker patients were treated with shunts with double ventricular catheters and Y shaped connection (Table 7) (Figure 6).

Table 7: The type of operation done for patients with hydrocephalus.

\begin{tabular}{|c|c|c|}
\hline $\begin{array}{c}\text { Type of operation } \\
\text { done }\end{array}$ & Frequency & Percent \\
\hline $\begin{array}{c}\text { MP VP shunt } \\
\text { posterior approach }\end{array}$ & 115 & $87.8 \%$ \\
\hline $\begin{array}{c}\text { MP VP shunt anterior } \\
\text { approach }\end{array}$ & 5 & $3.8 \%$ \\
\hline EVD & 5 & $3.8 \%$ \\
\hline $\begin{array}{c}\text { cystoperotineal } \\
\text { shunt }\end{array}$ & 3 & $2.3 \%$ \\
\hline $\begin{array}{c}\text { VP shunt with Y } \\
\text { connector }\end{array}$ & 131 & $2.3 \%$ \\
\hline Total & & $100 \%$ \\
\hline
\end{tabular}

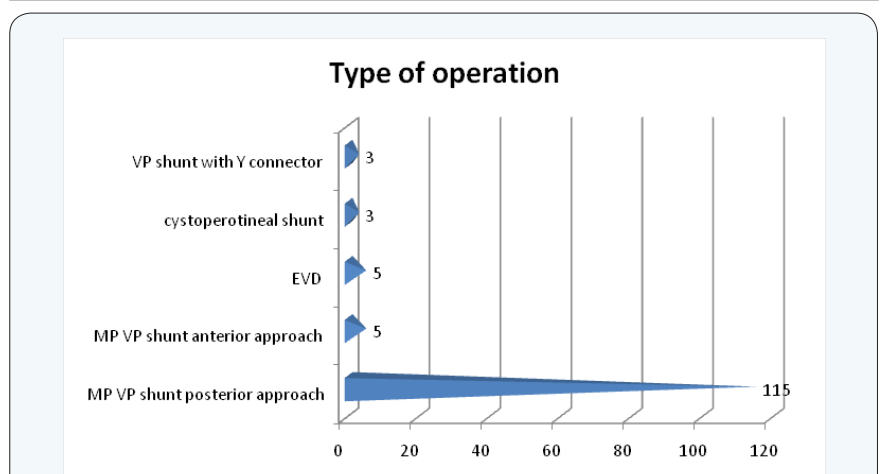

Figure 6: The type of operation done for patients with hydrocephalus. 


\section{Intraoperative CSF opening pressure}

The CSF opening pressure was assessed clinically intraoperatively upon tapping the ventricles and almost all of the patients were having high opening pressure (Table 8) (Figure 7).

Table 8: the intra-operative opening pressure before inserting the ventricular catheter.

\begin{tabular}{|c|c|c|}
\hline CSF opening pressure & Frequency & Percent \\
\hline High & 122 & $93.1 \%$ \\
\hline Medium & 4 & $3.1 \%$ \\
\hline low & 5 & $3.8 \%$ \\
\hline Total & 131 & $100 \%$ \\
\hline
\end{tabular}

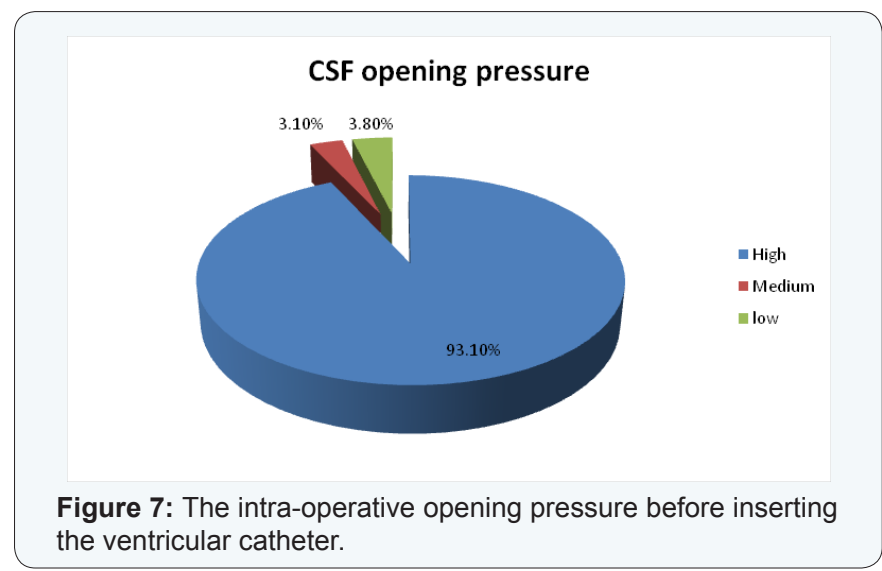

\section{Type of shunt used}

Different types of shunt systems have been used in our center but Medtronic was the commonly used one for being supported for free for under 5 years kids by some non-governmental organizations (Table 9).

Table 9: The type of shunt system used.

\begin{tabular}{|c|c|c|}
\hline Shunt type used & Frequency & Percent \\
\hline Medtronic & 113 & 86.3 \\
\hline Chhabra & 3 & 2.3 \\
\hline BMI & 12 & 9.2 \\
\hline $\begin{array}{c}\text { AB imprignated } \\
\text { shunt }\end{array}$ & 3 & 2.3 \\
\hline Total & 131 & 100.0 \\
\hline
\end{tabular}

\section{Shunt Complications}

The complications encountered were in a form of infected CSF (4 patients), shunt exposure (4 patients), bloody CSF (2 patients, one of them had S.D.H. with I.V.H.) and shunt dysfunction (4 patients) (Table 10).
Table 10: Shunt complications.

\begin{tabular}{|c|c|c|}
\hline Shunt complications & Frequency & Percent \\
\hline Yes & 14 & $10.7 \%$ \\
\hline No & 117 & $89.3 \%$ \\
\hline Total & 131 & $100 \%$ \\
\hline
\end{tabular}

For the reason that shunt implantation is a lifelong commitment we considered all patients who improved after shunt procedure or during follow up within "improved" category. The late shunt complications after 3 years are not included in this study (Table 11) (Figure $8 \&$ 9).

Table 11: The early outcome of shunt operation.

\begin{tabular}{|c|c|c|}
\hline Outcome & Frequency & Percent \\
\hline Improved & 123 & $93.9 \%$ \\
\hline Static & 2 & $1.5 \%$ \\
\hline Deteriorated & 6 & $4.6 \%$ \\
\hline Total & 131 & $100 \%$ \\
\hline
\end{tabular}

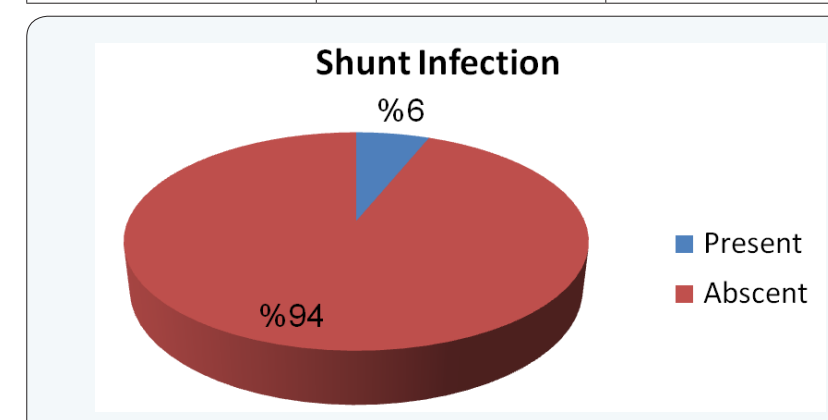

Figure 8: The shunt infection within the first 1 year of shunt placement.

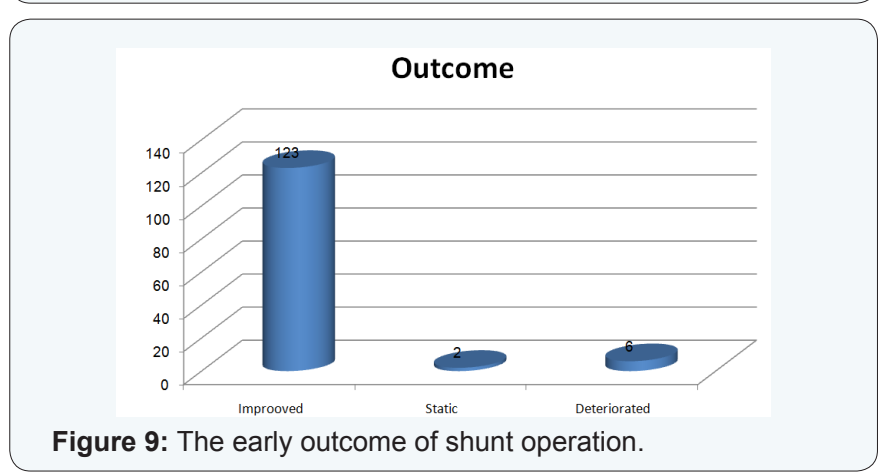

\section{The improvement parameters}

The improvement parameters used in this study were mainly clinical in a form of depressed Anterior fontanelle (AF) stoppage of CSF leak, Stoppage of Vomiting (V), lax AF (soft fontanelle neither bulging nor depressed), other parameters of improvement include improvement of developmental milestones whether mental or physical (Table 12) (Figure 10). 
Table 12: The parameters used to assess the post-operative improvement.

\begin{tabular}{|c|c|c|}
\hline $\begin{array}{c}\text { Improvement } \\
\text { parameters }\end{array}$ & Frequency & Percent \\
\hline depressed AF & 57 & 43.5 \\
\hline $\begin{array}{c}\text { depressed AF and } \\
\text { CSF leak stop }\end{array}$ & 1 & .8 \\
\hline H/A subsided & 1 & .8 \\
\hline $\begin{array}{c}\text { H/A subsided and V } \\
\text { stopped }\end{array}$ & 2 & 1.5 \\
\hline lax AF & 69 & .8 \\
\hline Some LL movement & 1 & 100.0 \\
\hline Total & 131 & \\
\hline
\end{tabular}

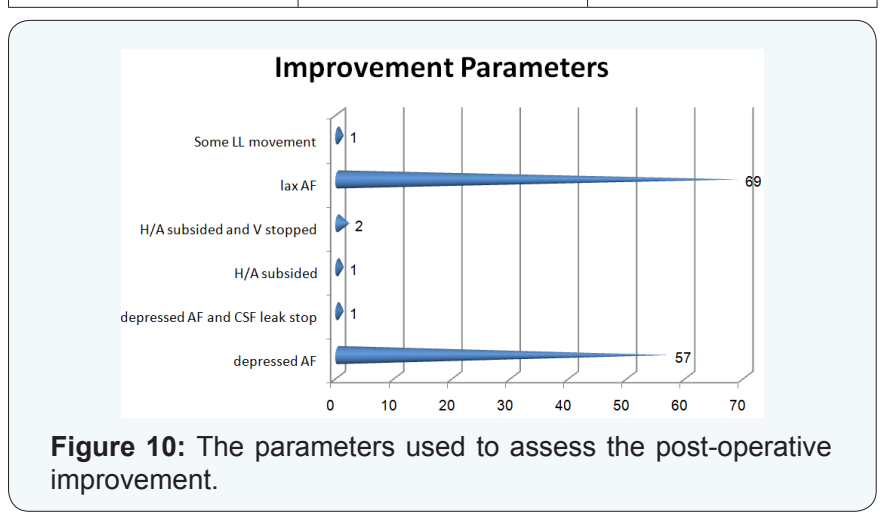

\section{Antenatal Care (A.N.C.)}

We divided the patients from thee antenatal care and tonics and vitamins supplement points of view into 3 main categories (Figure 11)

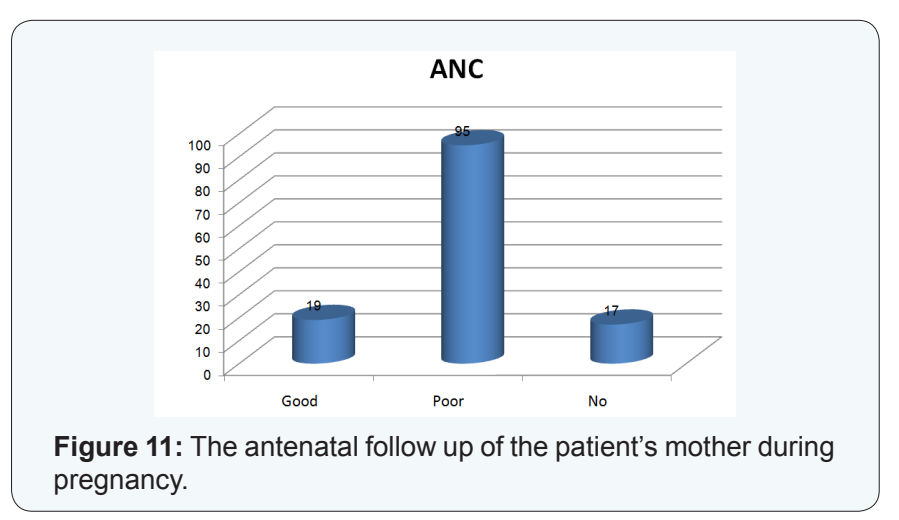

Patients with good antenatal care: Those are children of mothers who attended regularly ante natal care visits and who received the tonics from the early beginning of the pregnancy (the first month of pregnancy)

Patients with poor antenatal care: Those are children of mothers who did not attended regularly antenatal care visits and who started to receive the tonics after the end of the first trimester.

Patients without antenatal care: Those who did not attend antenatal care visits and/or who did not receive tonics throughout the pregnancy.

\section{Pregnancy complications}

Mothers of four patients were found to have problems during pregnancy, two of them had malaria, one has Pregnancy Induced Hypertension (PIH) and the last recurrent Urinary Tract Infection (UTI).

\section{Family history of similar condition}

None of the patients was found to have FH of similar condition.

\section{Discussion}

The average age at presentation was Eleven months. This late presentation may be attributed to the lack of the neurosurgical services in the remote areas. The youngest child operated was Fifteen days old and the oldest was Twelve years old. However, most of the patients present between birth up to Three months, followed with those between Four to Six months and that is why most of the operated patients were children in the pre-school age. Male sex was the dominant, but this may not have very much significance in this study.

Most of the patients were from Khartoum and the central area because the national center for neurosciences beside the two other governmental centers and some other private centers are all in Khartoum. This is followed by those from the Western part of Sudan (Darfur and Kordofan) as these regions has the highest number of population in Sudan after Khartoum and the possibility of the effect of political conflicts and war refugees which has created nutritional and health impacts on the ladies in the childbearing age.

As a result of the poor antenatal follow up and the illiteracy the diagnosis was usually late and made only after the child head increases. That is why those who presented with large head were representing the majority of our patients. $78.6 \%$ percent of the patients were found to have congenital problems like Chiari malformation accompanying spina bifida followed by acquiductal stenosis, and in $17.6 \%$ it was postmeningitic type of hydrocephalus. Therefore the congenital etiology was on the top of the list followed with the infectious etiology and this can also justify the presentation with large head. Furthermore, most of the cases were young children and a many of them had large occipital horns and small frontal horn (colpocephaly) that is why we approached most of the patient through Keen's point using fixed medium pressure valves despite the fact that the opening CSF pressure in the vast majority of patients intra-operatively was relatively high pressure. Although in the literature Sinha et al studied Tourty patients with pediatric hydrocephalus and they discovered that there is no difference in the outcome 


\section{Open Access Journal of Neurology \& Neurosurgery}

with low or medium pressure valves [18]. But still this point is not clear in treating hydrocephalus as logically high opening pressure hydrocephalus treated with placement of low pressure shunt may lead to Medtronic, BMI, Chabra and antibiotic impregnated shunts were all used with Medtronic being the most commonly used one as it was provided free for the patients with nongovernmental organizations.

Fortunately, we had an acceptable outcome as those who had shunt complications were only $10.7 \%$ and those with postoperative shunt infection were only $6.1 \%$. This is because we adopted a rigid protocol to prevent shunt infection (short preoperative admission one night before surgery, and discharge two days after surgery, baby wash with soap the day before surgery, first operation in the day, few number of personnels in the room not more than 6 , scrubbing with 2 different solutions, non touch technique and change of gloves upon shunt insertion and using 2 different types of antibiotics postoperatively). The final outcome was promising as most of the patients improved postoperatively. We used simple clinical assessment ways to primary assess the improvement like depressed Anterior fontanelle (AF) stoppage of CSF leak, relieve of headache (H/A), Stoppage of Vomiting (V), lax AF. The strongest parameter was lax or depressed AF.

The presence of associated congenital anomalies makes the management much more difficult. More than one third of the patients in this study were having associated myelomeningocele with few of them had other congenital CNS anomalies.

Most of the mothers (72.5\%) of the affected children started to receive the folic acid after the end of the first trimester while considerable number of them did not receive any folic acid throughout the pregnancy. This may reflect the association of folic acid deficiency with the development of hydrocephalus. Only few of the mothers were found to have problems during pregnancy like malaria, PIH recurrent UTI. However, the association of these conditions with the development of hydrocephalus needs further studies to evaluate the pathogenesis and the correlations if any.

\section{Conclusion}

Early detection and management of hydrocephalus, is associated with easy treatment and better outcome.

It is important to increase the awareness of the medical professionals and the general populations will decrease the overall incidence of hydrocephalus. Involvement of the general media is incredibly important.

The use of strict meticulous aseptic technique during the operative procedure is crucial in preventing shunt infection and most other serious complications. The ventriculoperitoneal shunt procedure is not an easy one and should be performed by the most experienced neurosurgeon under the most optimum condition.
The follow up of the patients should be adequate as those children might have long term complications and disabilities.

\section{Recommendations}

Fortification of the wheat flour will help the ladies in childbearing age to have good maternal serum folic acid level. Otherwise the mothers should be taught the importance of taking folic acid early in the beginning of pregnancy. Proper antenatal care is mandatory for women in child bearing age specially who has history of child birth with CNS deformities the role of media medical education in this matter is so valuable. Adopting rigid national protocol to prevent shunt infection will be useful even in the presence of associated risk factors like malnutrition.

\section{References}

1. Melo JR, de Melo EN, de Vasconcellos AG, Pacheco P (2013) Congenital hydrocephalus in the northeast of Brazil: epidemiological aspects, prenatal diagnosis, and treatment. Childs Nerv Syst 29(10): 18991903.

2. Albright AL (2010) Hydrocephalus shunt practice of experienced pediatric neurosurgeons. Childs Nerv Syst 26(7): 925-929.

3. Bayston R (1994) Hydrocephalus shunt infections. J Antimicrob Chemother 34(Suppl A): 75-84.

4. Bayston R, Compton C, Richards K (1994) Production of extracellular slime by coryneforms colonizing hydrocephalus shunts. J Clin Microbiol 32(7): 1705-1709.

5. Bayston R, Ashraf W, Barker-Davies R, Tucker E, Clement R, et al. (2007) Biofilm formation by Propionibacterium acnes on biomaterials in vitro and in vivo: impact on diagnosis and treatment. J Biomed Mater Res A 81(3): 705-709.

6. Bayston R, Vera L, Ashraf W (2010) Activity of an antimicrobial hydrocephalus shunt catheter against Propionibacterium acnes. Antimicrob Agents Chemother 54(12): 5082-5085.

7. Brydon HL, Bayston R, Hayward R, Harkness W (1996) Reduced bacterial adhesion to hydrocephalus shunt catheters mediated by cerebrospinal fluid proteins. J Neurol Neurosurg Psychiatry 60(6): 671-675.

8. Brydon HL, Keir G, Thompson EJ, Bayston R, Hayward R, et al. (1998) Protein adsorption to hydrocephalus shunt catheters: CSF protein adsorption. J Neurol Neurosurg Psychiatry 64(5): 643-647.

9. Allin DM, Czosnyka ZH, Czosnyka M, Richards HK, Pickard JD (2006) In vitro hydrodynamic properties of the Miethke ProGAV hydrocephalus shunt. Cerebrospinal Fluid Res 3: 9.

10. Allin DM, Czosnyka M, Richards HK, Pickard JD, Czosnyka ZH (2008) Investigation of the hydrodynamic properties of a new MRI-resistant programmable hydrocephalus shunt. Cerebrospinal Fluid Res 5: 8.

11. Bogdanovic R, Nikolic V, Ognjanovic M, Marjanović B, Sindjić M, et al. (1996) Shunt nephritis. 2 case reports and a review of the literature. Srp Arh Celok Lek 124(1-2): 29-36. [Article in Serbian].

12. Chhabra DK, Agrawal GD, Mittal P (1993) "Z" flow hydrocephalus shunt, a new approach to the problem of hydrocephalus, the rationale behind its design and the initial results of pressure monitoring after "Z" flow shunt implantation. Acta Neurochir (Wien) 121(1-2): 43-47.

13. Czosnyka ZH, Czosnyka M, Richards HK, Pickard JD (2001) Laboratory evaluation of the phoenix CRx diamond valve. Neurosurgery 48(3): 689-693. 


\section{Open Access Journal of Neurology \& Neurosurgery}

14. Eymann R, Meier U, Kiefer M (2010) Animal experiments to evaluate complications of foreign materials on silicone with shunt catheters: preliminary results. Acta Neurochir Suppl 106: 91-93.

15. Eymann R, Kim YJ, Bohle RM, Antes S, Schmitt M, et al. (2012) Microstructural alterations of silicone catheters in an animal experiment: histopathology and SEM findings. Acta Neurochir Suppl 113: 87-90.

16. Goetz C, Foertsch D, Schoenberger J, Uhl E (2005) Thermography - a valuable tool to test hydrocephalus shunt patency. Acta Neurochir (Wien) 147(11): 1167-1172.
17. Jain G, Mukerji G, Dixit A, Manshani N, Yadav YR (2007) The impact of nutritional status on the outcome of Indian patients undergoing neurosurgical shunt surgery. Br J Nutr 98(5): 944-949.

18. Sinha A, Sharma A, Gupta C (2012) Pediatric hydrocephalus: Does the shunt device pressure selection affect the outcome? J Indian Assoc Pediatr Surg 17(2): 54-57.

Your next submission with JuniperPublishers will reach you the below assets

- Quality Editorial service

- Swift Peer Review

- Reprints availability

- E-prints Service

- Manuscript Podcast for convenient understanding

- Global attainment for your research

- Manuscript accessibility in different formats ( Pdf, E-pub, Full Text, audio)

- Unceasing customer service

Track the below URL for one-step submission https://juniperpublishers.com/online-submission.php 